\begin{tabular}{|c|c|c|}
\hline \multirow{3}{*}{$\begin{array}{r}\text { Case Reports in } \\
\text { Gastroenterology }\end{array}$} & \multirow{2}{*}{\multicolumn{2}{|c|}{ Case Rep Gastroenterol 2013;7:476-481 }} \\
\hline & & \\
\hline & $\begin{array}{l}\text { DOI: 10.1159/000356825 } \\
\text { Published onlIne: November 12, } 2013\end{array}$ & $\begin{array}{l}\text { (c) } 2013 \text { S. Karger AG, Basel } \\
\text { 1662-0631/13/0073-0476 } \$ 38.00 / 0 \\
\text { www.karger.com/crg }\end{array}$ \\
\hline & \multicolumn{2}{|c|}{$\begin{array}{l}\text { This is an Open Access article licensed under the terms of the Creative Commons } \\
\text { Attribution-NonCommercial } 3.0 \text { Unported license (CC BY-NC) (www.karger.com/OA } \\
\text { license), applicable to the online version of the article only. Distribution permitted for non } \\
\text { commercial purposes only. }\end{array}$} \\
\hline
\end{tabular}

\title{
Systemic Reactive Amyloidosis Associated with Castleman's Disease
}

\author{
Vinaya Gaduputi Hassan Tariq Kanthi Badipatla Ariyo Ihimoyan \\ Department of Medicine, Bronx Lebanon Hospital Center, New York, N.Y., USA
}

\section{Key Words}

Secondary amyloidosis · Castleman's disease · Systemic reactive amyloidosis . AA amyloidosis · Amyloidosis in Castleman's disease

\begin{abstract}
We report this case of secondary amyloidosis associated with Castleman's disease. A 51-yearold man presented with systemic symptoms of generalized weakness, fatigue, unintended weight loss, anorexia and progressively worsening abdominal distension. On examination he was found to have an indurated right-sided submandibular mass and tense ascites. He was found to have multiorgan dysfunction with deranged liver function tests and renal failure. Ascitic fluid analysis revealed evidence of spontaneous bacterial peritonitis. Biopsy of the submandibular mass revealed angiofollicular lymph node hyperplasia consistent with a diagnosis of Castleman's disease. A subsequent liver biopsy showed extensive deposition of amyloid protein. Bone marrow biopsy also showed the presence of amyloid and increased kappa light chain-restricted plasma cells. The patient was not considered a candidate for chemotherapy or solid organ transplantation in view of active sepsis and poor physical condition. Secondary systemic amyloidosis complicating Castleman's disease is very rare. Untreated secondary systemic amyloidosis often has a rapidly fatal course, such as seen in our patient.

(c) 2013 S. Karger AG, Basel
\end{abstract}

\section{Introduction}

Castleman's disease is a rare B-cell non-clonal lymphoproliferative disorder first described over 50 years ago characterized by its variegated presentation. It can practically affect any region within the body, the most common being the chest in about $70 \%$, the abdomen in about $15 \%$ and the remaining occurring within the neck [1]. This condition may

Hassan Tariq, MD

Department of Medicine, Bronx Lebanon Hospital Center

1650 Selwyn Ave, Suite \#10C, Bronx, New York, N.Y. 10457 (USA)

E-Mail htariq@bronxleb.org 
Gaduputi et al.: Systemic Reactive Amyloidosis Associated with Castleman's Disease

resemble other entities causing lymphadenopathy including lymphomas, infectious or inflammatory causes.

The predominant histopathological variants include the more common hyaline vascular type, the plasma cell type which is usually associated with POEMS syndrome, Castleman's disease seen with HHV-8 infection usually found in HIV and immunosuppressed patients and an unspecified form of multicentric Castleman's disease. Patients are usually found to have anemia and polyclonal hypergammaglobulinemia [1].

Castleman's disease is clinically classified into a unicentric variety, which is usually asymptomatic, or a multicentric variety, which can be associated with systemic inflammatory state manifesting with constitutional symptoms such as fever, night sweats and weight loss, depending on the number of lymph nodes involved [1,2]. In certain cases, this systemic inflammatory state can be complicated by secondary amyloidosis characterized by deposition of serum amyloid A protein within the extracellular tissue. Castleman's disease has not demonstrated any sex predilection, with unicentric variety peaking in incidence within the second to fourth decades of life, while multicentric variety occurs in older populations [3].

Secondary (AA) amyloidosis has been reported with both unicentric [4] and multicentric variants [5] of Castleman's disease. The prognosis of Castleman's disease is related to the extent of systemic involvement either directly from the disease itself or from co-existing systemic amyloidosis. Multicentric disease carries a dismal prognosis with an often rapidly fatal course. Untreated systemic amyloidosis also often has an unrelenting clinical course, leading to multiorgan failure and death. The degree of regression of amyloidosis itself is often contingent upon the variant of Castleman's disease, with surgical excision of the primary tumor in a unicentric variant being potentially curative [1, 2].

We report a rare association of unicentric Castleman's disease with secondary (AA) amyloidosis.

\section{Case Report}

A 51-year-old African-American man who had been born and raised in the United States first presented to the medical clinic with complaints of generalized weakness, fatigue, unintended weight loss, anorexia and progressively worsening abdominal distension of 3 months duration. His medical comorbidities included essential hypertension and gout. Physical examination at the time was significant for a firm, indurated right-sided submandibular mass, hepatomegaly and mild epigastric tenderness.

An initial set of laboratory studies showed abnormal liver enzymes (alanine transaminase of $61 \mathrm{IU} / \mathrm{l}$, aspartate transaminase of $83 \mathrm{IU} / \mathrm{l}$, markedly elevated alkaline phosphatase of 1,003 IU/l and gamma-glutamyl transferase of 1,879 IU/l with normal bilirubin levels). Additional work-up done for evaluation of abnormal liver enzymes including viral hepatitis panels (hepatitis A, B and C), anti-nuclear antibody, anti-smooth muscle antibody, anti-liver kidney microsomal antibodies and anti-mitochondrial antibody were negative. A computed tomography scan of the abdomen showed hepatomegaly $(18 \mathrm{~cm})$.

The patient underwent biopsy of the submandibular mass that revealed features of Castleman's disease (fig. 1). A subsequent liver biopsy revealed perisinusoidal deposition of eosinophilic, amorphous material within the extracellular matrix with hepatocyte atrophy, consistent with hepatic amyloidosis (fig. 2). Bone marrow biopsy revealed diffuse extracellular eosinophilic, amorphous material consistent with amyloidosis with increased kappa light chain-restricted plasma cell count (6\% of hematopoietic bone marrow cells) (fig. 3). The patient underwent a colonoscopy that revealed no gross mucosal lesions; biopsies were un- 
Gaduputi et al.: Systemic Reactive Amyloidosis Associated with Castleman's Disease

remarkable. A definitive diagnosis of secondary (AA) reactive amyloidosis with hepatic involvement was made.

The patient had subsequent hospitalized with new-onset, rapidly progressing tense ascites. He underwent large-volume paracentesis. Ascitic fluid analysis revealed an elevated serum-ascites albumin gradient of 1.7 and very low protein of $0.9 \mathrm{~g} / \mathrm{dl}$. Cell count analysis was consistent with spontaneous bacterial peritonitis. He was treated with intravenous antibiotics. A computed tomography scan of the abdomen done at the time revealed dilated loops of small bowel consistent with small bowel obstruction, which resolved with conservative management. He was not considered for chemotherapy in view of active infection and was not a liver transplant candidate because of his poor physical condition. The patient was discharged to be readmitted only 2 weeks later with recurrent ascites from decompensated liver disease. He was found to have worsening jaundice. His clinical condition rapidly deteriorated with superimposed severe metabolic acidosis resulting from acute renal dysfunction. He ultimately expired from multiorgan failure.

\section{Discussion}

Castleman's disease often presents in sixth to seventh decades of life [6] with more than half of affected patients being male. Patients with multicentric Castleman's disease universally present with peripheral lymphadenopathy as seen in our patient. Only a few cases of secondary (AA) amyloidosis complicating Castleman's disease [7-9] have been reported in the literature. Secondary (AA) amyloidosis complicates chronic conditions with ongoing inflammation. Extensive hepatic involvement from primary systemic amyloidosis is seen in almost two-thirds of the patients $[10,11]$, but to a lesser degree in secondary (AA) amyloidosis $[12,13]$. Hepatic amyloidosis is often asymptomatic, the most common presentations being hepatomegaly in more than two-thirds of those affected and elevated alkaline phosphatase [14]. Hepatic amyloidosis is characterized by parenchymal replacement by amyloid leading to pressure atrophy of the hepatocytes. Ascites, as seen in our patient, is a rare finding and is often a function of decreased cardiac contractility from amyloid infiltration or hypoalbuminemia from nephrotic syndrome. Our patient had a normal cardiac ejection fraction of $71 \%$ on echocardiogram, but was profoundly hypoalbuminemic from heavy proteinuria. He was observed to have cholestatic liver function tests with jaundice, which is exceedingly rare and often portends poor outcome $[15,16]$. He also likely had collateral gastrointestinal amyloidosis with symptoms like unintended weight loss and was found to have intestinal pseudo-obstruction as well, which likely resulted from enteric neuropathy from amyloid deposition [17].

It has been noted in a small-size study that use of ursodeoxycholic acid could be of benefit in hepatic amyloidosis, with improvement in serum alkaline phosphatase and gammaglutamyl transferase levels [18]. The role of liver transplantation was studied extensively in familial variants of amyloidosis [19-21], to a lesser degree in primary (AL) amyloidosis [22], but not in secondary reactive amyloidosis. However, the crux of treatment of secondary (AA) reactive amyloidosis lies at treating the underlying precipitating inflammatory condition. There has been a steady increase in survival in patients with reactive amyloidosis secondary to advances in treatment strategies for underlying inflammatory disorders [23]. Excision of unicentric Castleman's tumor often leads to regression of AA amyloidosis by suppressing cytokine production [4]. However, our patient did not show an optimal clinical response even after excisional biopsy of the submandibular Castleman's tumor. 
Gaduputi et al.: Systemic Reactive Amyloidosis Associated with Castleman's Disease

To our knowledge, this case is one amongst only few that presented systemic amyloidosis complicating Castleman's disease. This case is unique in that extensive, diffuse amyloid deposits were observed in the liver with cholestatic jaundice. It is also the first reported case where secondary amyloidosis failed to regress even after removal of the primary trigger, the focal Castleman's tumor.

\section{Disclosure Statement}

The authors do not have a direct financial relation with the commercial identities mentioned in the paper that might lead to a conflict of interest.

\section{References}

1 Bonekamp D, Horton KM, Hruban RH, Fishman EK: Castleman disease: the great mimic. Radiographics 2011;31:1793-1807.

-2 Tanaka K, Horita M, Shibayama H, Seike M, Itoh Y, Hamaguchi K, Sato Y, Sakata T, Ishida T: Secondary amyloidosis associated with Castleman's disease. Intern Med 1995;34:122-126.

-3 Keller AR, Hochholzer L, Castleman B: Hyaline-vascular and plasma-cell types of giant lymph node hyperplasia of the mediastinum and other locations. Cancer 1972;29:670-683.

-4 Shimojima Y, Takei Y, Tazawa K, Gono T, Fushimi T, Matsuda M, Hoshii Y, Ikeda S: Histopathological regression of systemic AA amyloidosis after surgical treatment of a localized Castleman's disease. Amyloid 2006;13:184-186.

5 Ogita M, Hoshino J, Sogawa Y, Sawa N, Katori H, Takemoto F, Ubara Y, Hara S, Miyakoshi S, Takaichi K: Multicentric Castleman disease with secondary AA renal amyloidosis, nephrotic syndrome and chronic renal failure, remission after high-dose melphalan and autologous stem cell transplantation. Clin Nephrol 2007;68:171-176.

-6 Frizzera G, Peterson BA, Bayrd ED, Goldman A: A systemic lymphoproliferative disorder with morphologic features of Castleman's disease: clinical findings and clinicopathologic correlations in 15 patients. J Clin Oncol 1985;3:1202-1216.

7 Yamagata N, Fujio J, Hirai R, Matsumaru M, Tanimura S, Inokuchi C, Shikai T, Takezako N, Nasu M, Sakata Y, Sata N, Nagai H, Saito K, Miwa A: Marked hepatomegaly due to AA type amyloidosis in a case with Castleman's disease. Int J Hematol 2006;84:70-73.

-8 Franco V, Aragona F, Rodolico V, Barbagallo Sangiorgi G, Fradà G Jr, Campesi G: Castleman's disease associated with hepatic amyloidosis. An immunohistochemical and ultrastructural study. Haematologica 1984;69:556-567.

-9 Ordi J, Grau JM, Junqué A, Nomdedeu B, Palacin A, Cardesa A: Secondary (AA) amyloidosis associated with Castleman's disease. Report of two cases and review of the literature. Am J Clin Pathol 1993;100:394-397.

10 Buck FS, Koss MN: Hepatic amyloidosis: morphologic differences between systemic AL and AA types. Hum Pathol 1991;22:904-907.

11 Park MA, Mueller PS, Kyle RA, Larson DR, Plevak MF, Gertz MA: Primary (AL) hepatic amyloidosis: clinical features and natural history in 98 patients. Medicine (Baltimore) 2003;82:291-298.

12 Brandt K, Cathcart ES, Cohen AS: A clinical analysis of the course and prognosis of forty-two patients with amyloidosis. Am J Med 1968;44:955-969.

-13 Pelletier G, Fabre M, Attali P, Ladouch-Badre A, Ink O, Martin E, Etienne JP: Light chain deposition disease presenting with hepatomegaly: an association with amyloid-like fibrils. Postgrad Med J 1988;64:804-808. Kyle RA, Bayrd ED: Amyloidosis: review of 236 cases. Medicine (Baltimore) 1975;54:271-299.

15 Peters RA, Koukoulis G, Gimson A, Portmann B, Westaby D, Williams R: Primary amyloidosis and severe intrahepatic cholestatic jaundice. Gut 1994;35:1322-1325.

16 Konikoff F, Mor C, Stern S, Shaklai M, Halevy J, Theodor E: Cholestasis and liver failure with lambda-AL amyloidosis. Gut 1987;28:903-906.

17 Legge DA, Wollaeger EE, Carlson HC: Intestinal pseudo-obstruction in systemic amyloidosis. Gut 1970;11: $764-767$.

18 Faust D, Akoglu B, Ristic G, Milovic V: Ursodeoxycholic acid for treatment of cholestasis in patients with hepatic amyloidosis. Vojnosanit Pregl 2009;66:482-486.

19 Grazi GL, Cescon M, Salvi F, Ercolani G, Ravaioli M, Arpesella G, Magelli C, Grigioni F, Cavallari A: Combined heart and liver transplantation for familial amyloidotic neuropathy: considerations from the hepatic point of view. Liver Transpl 2003;9:986-992. 
Gaduputi et al.: Systemic Reactive Amyloidosis Associated with Castleman's Disease

20 Holmgren G, Ericzon BG, Groth CG, Steen L, Suhr O, Andersen O, Wallin BG, Seymour A, Richardson S, Hawkins PN, et al: Clinical improvement and amyloid regression after liver transplantation in hereditary transthyretin amyloidosis. Lancet 1993;341:1113-1116.

-21 Stangou AJ, Hawkins PN: Liver transplantation in transthyretin-related familial amyloid polyneuropathy. Curr Opin Neurol 2004;17:615-620.

-22 Sattianayagam PT, Gibbs SD, Pinney JH, Wechalekar AD, Lachmann HJ, Whelan CJ, Gilbertson JA, Hawkins PN, Gillmore JD: Solid organ transplantation in AL amyloidosis. Am J Transplant 2010;10:2124-2131.

-23 Lachmann HJ, Goodman HJ, Gilbertson JA, Gallimore JR, Sabin CA, Gillmore JD, Hawkins PN: Natural history and outcome in systemic AA amyloidosis. New Engl J Med 2007;356:2361-2371.

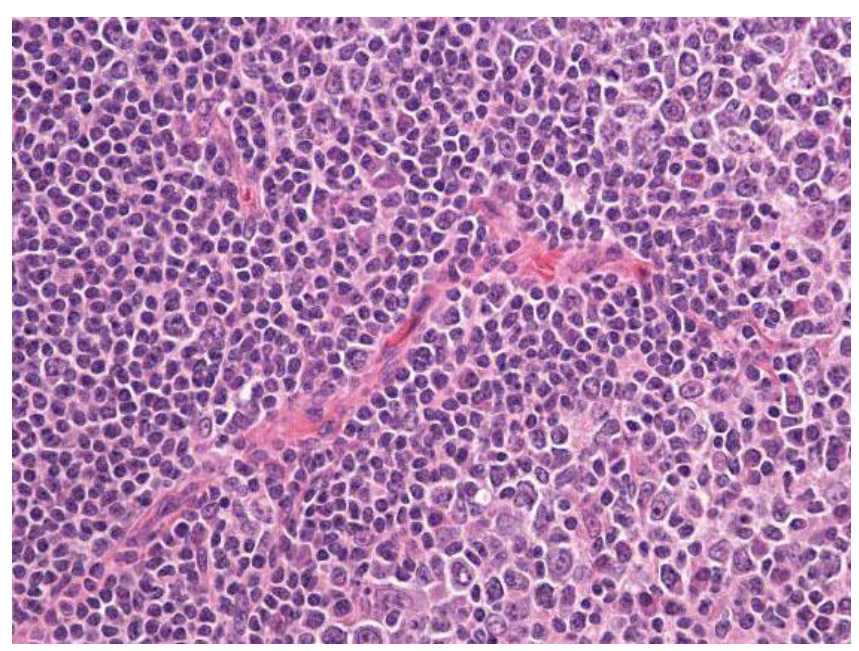

Fig. 1. Submandibular mass biopsy revealing florid follicular hyperplasia along with eosinophilic cell infiltration, focal fibrosis and giant cell reaction.

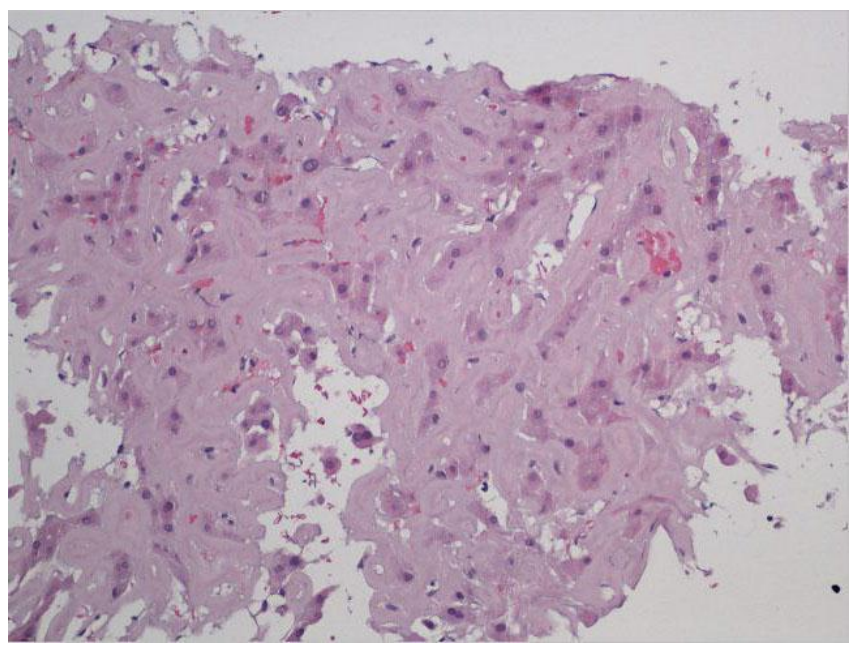

Fig. 2. Liver biopsy revealing perisinusoidal deposition of eosinophilic, amorphous material within the extracellular matrix with hepatocyte atrophy, consistent with hepatic amyloidosis. 


\begin{tabular}{ll|l} 
Case Reports in & \multicolumn{2}{l}{ Case Rep Gastroenterol 2013;7:476-481 } \\
\cline { 2 - 3 } Gastroenterology & $\begin{array}{l}\text { DO 2013 S. Karger AG, Basel } \\
\text { www.karger.com/crg }\end{array}$ \\
\cline { 2 - 3 } & Gaduputi et al.: Systemic Reactive Amyloidosis Associated with Castleman's Disease
\end{tabular}

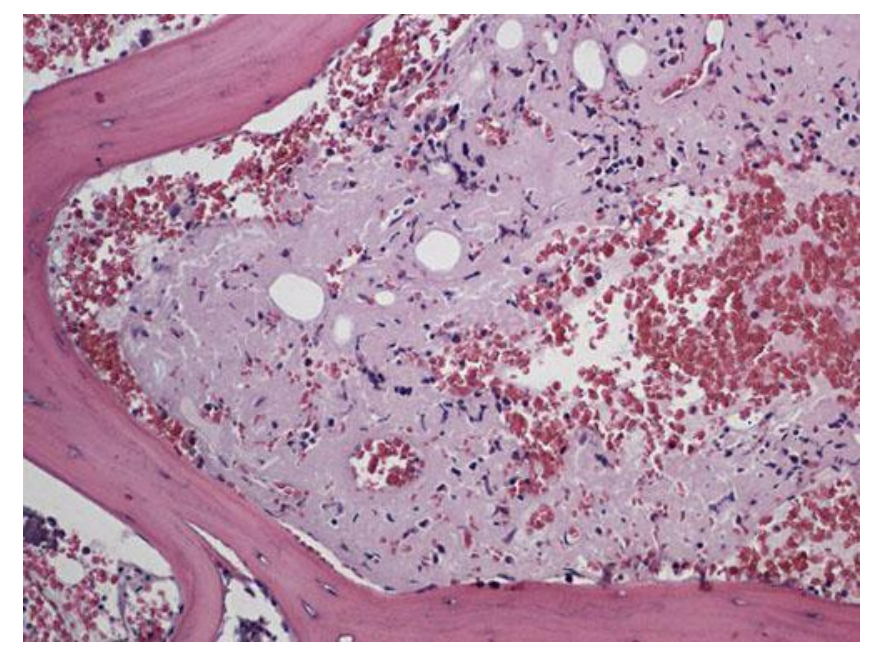

Fig. 3. Bone marrow biopsy revealing diffuse extracellular eosinophilic, amorphous material consistent with amyloidosis. 